\title{
Assessing the incidence of common bean (Phaseolus vulgaris L.) infection by fungi during harvest and storage in Cameroon
}

\author{
Akwa TE ${ }^{1, *}$, Maingi $\mathrm{JM}^{1}$ and Birgen $\mathrm{JK}^{2}$ \\ ${ }^{1}$ Department of Biochemistry, Microbiology and Biotechnology, Kenyatta University, Nairobi, Kenya \\ ${ }^{2}$ Department of Plant Sciences, Kenyatta University, Nairobi, Kenya
}

Akwa TE, Maingi JM, Birgen JK 2020 - Assessing the incidence of common bean (Phaseolus vulgaris L.) infection by fungi during harvest and storage in Cameroon. Studies in Fungi 5(1), 435446, Doi 10.5943/sif/5/1/24

\begin{abstract}
In most parts of Cameroon particularly the Menoua Division, common bean (Phaseolus vulgaris L.) is usually consumed immediately after harvest or after a few months of storage. Contamination of common bean by fungi usually occurs in the field and during storage. It is possible that the incidence of food contamination by fungi varies between field and storage. The study aimed at determining the incidence of common bean infection by fungi during harvest and during storage. Six common bean cultivars both during harvest and storage were evaluated. Analysis of variance showed no significant difference $(\mathrm{P}>0.05)$ between their incidences of infection by fungi during harvest. The incidence of common bean infection during storage was shown to differ significantly between each cultivar $(\mathrm{P} \leq 0.05)$. A comparison of the mean incidence level of infection by fungi in the two groups of bean cultivars (cultivars during harvest and cultivars during storage) using the independent t- test analysis revealed a significant difference between their mean incidence of infection. The findings conclude that the incidence of common bean infection by fungi during storage is higher than during harvest in the Menoua Division. These findings will help to sensitise farmers on the improvement of bean storage conditions.
\end{abstract}

Key words - Africa - Identification - Menoua Division - Mold - Significant difference

\section{Introduction}

In Cameroon, common bean is the third most widely consumed legume after groundnut and cowpea (Kamtchoum et al. 2018). In the Western parts of Cameroon, the high nutrients value derived from common bean coupled to its ability to survive and grow even during changes in climates makes it the most important legume being cultivated (Buruchara et al. 2011). Common bean is regarded as one of the most available source of protein for the less privileged population especially the poor where about 30\% of the households live below the poverty line (Alemu 2017).

Though common bean has been shown to offer many economic and health benefits, its production has been negatively affected by various factors, amongst which are diseases (Ghangaokar et al. 2013). A majority of the diseases affecting common bean have being known to be caused by fungi. A few examples of fungal diseases associated with common bean includes; white mold disease caused by Sclerotinia sclerotiorum, anthracnose or black spot disease caused by Colletotrichum lindemuthianum, bean rust caused by fungus Uromyces appendiculatus and root rot disease caused by Fusarium solani f. sp. phaseoli (Seebold 2014). Infection of common bean by fungi can occur both in the field and after harvest in storage. Farmers in the Menoua Division of 
Cameroon after harvest store common bean in gunny bags for at least a period of 3 months after which the bean is made available for sale or as food. Studies done by Pitt \& Hocking (2009) has shown that the development of fungi on stored grains in gunny bags occurs months after being stored at room temperature. Fungal occurrence and incidence in common bean during harvest and storage is a major concern so as to safeguard seed health and its viability. Unfortunately, the information on fungal incidence on common bean has not been documented in Menoua Division, West region of Cameroon. The present investigation has therefore been undertaken to assess the incidence of common bean infection by fungi both during harvest and storage in Menoua Division, West Region of Cameroon.

\section{Materials and Methods}

\section{Study site}

The study took place in the Menoua Division, West Region of Cameroon in April 2019. Cameroon is a country situated in the central part of Africa (Fig. 1A). The country is made up of ten regions. The West region is one of these regions having the least population of inhabitants but the highest population density as compared to the other regions. The population census data of 2015 showed that 1, 921,600 inhabitants were found in the West Region (INS 2017). The West Region is composed of eight divisions or units having the Menoua Division (Fig. 1B) as one of them. The Menoua Division has two seasons; the rain and dry seasons. The rainy periods commence in April and end in September while the dry season begins from October to March. As of 2006 to 2011, the annual temperature value recorded in this region ranged between $13.66{ }^{\circ} \mathrm{C}$ to $25.35{ }^{\circ} \mathrm{C}$ and a rainfall of about $1717.70 \mathrm{~mm}$ (Seino et al. 2013). Agriculture is the primary economic activity practiced in the Menoua Division (Tankou et al. 2017). Different crops are produced in this division, the most important of which is the common bean with many varieties cultivated (Dongmo et al. 2014). The cultivation of common bean is done twice a year; in the month of March and August. The first cultivation begins in March and the second begins in August. Main production of common bean occurs in late rainy season (August) so that maturity coincides with dry weather (October to November). During the early rains, the production of common bean is less. This is because the bean will mature during heavy rains with attendant challenges of drying.

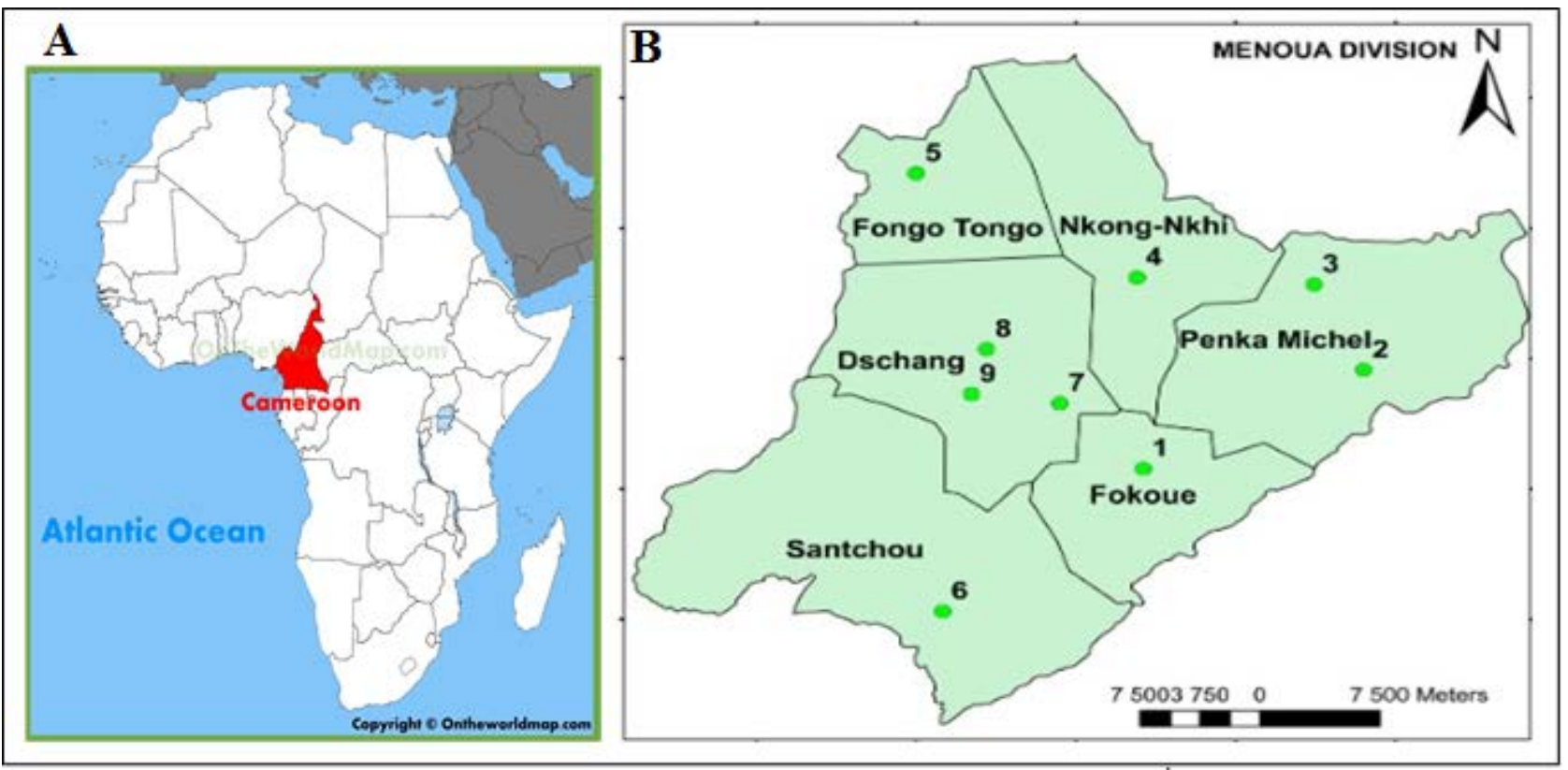

Fig. 1 - Location of the Study Area. A Location of Cameroon in Africa. B Sub Divisions in the Menoua Division. (Source: commons.wikimedia.org/wiki/Atlas of Cameroon) 


\section{Collection of common bean samples}

Common bean cultivars during harvest were collected from the farmers' field (farm land) while the stored bean cultivars were collected from their storage structures after being stored for three months after harvest (Fig. 2). Sampling was carried out by picking the common bean grains multiple times from these same storage bags using bowls.

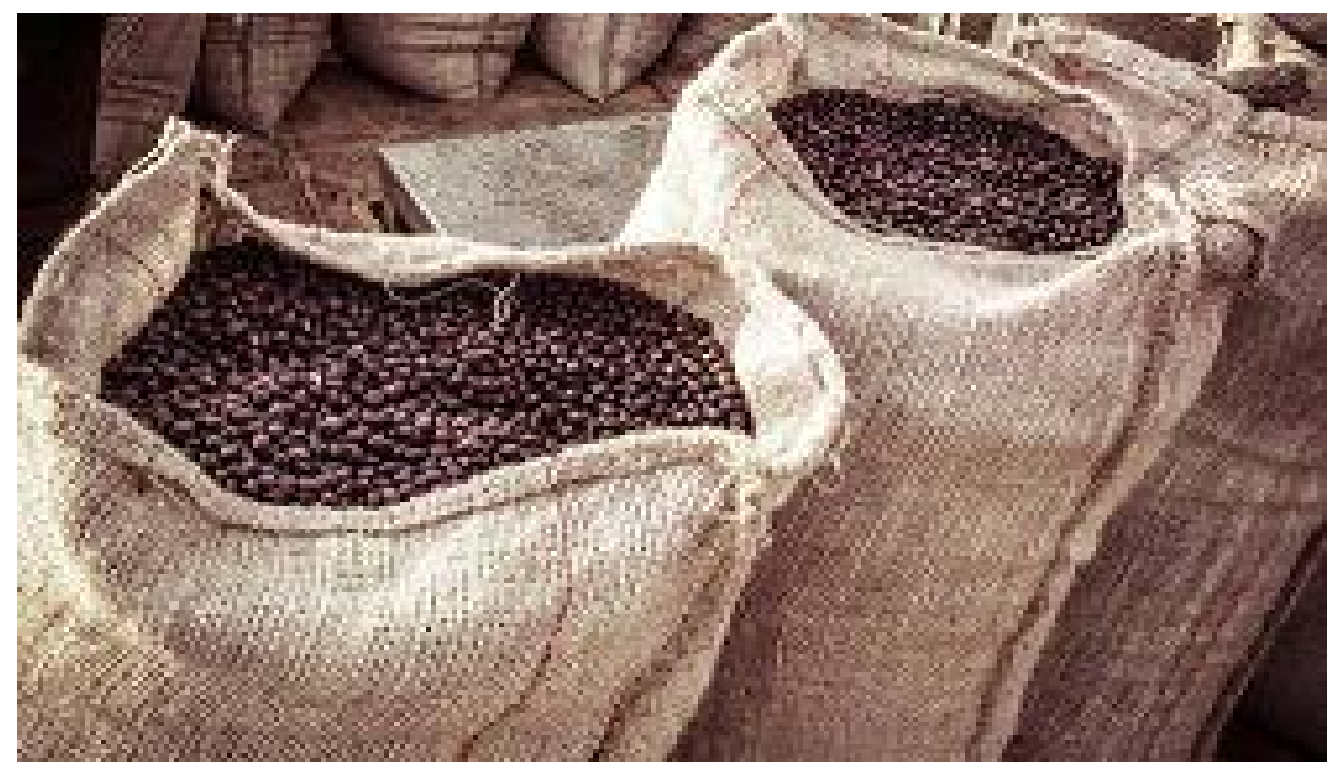

Fig. 2 - Gunny bags used in common bean storage in Menoua Division, Cameroon.

The samples were then mixed to form one homogenous sample that was then labelled appropriately. A total of 500 grams of each common bean cultivar (both at harvest and storage) was collected. These cultivars included; Black turtle bean (Black bean), Kidney bean (small sized red bean), Pea bean (mottled red bean), Navy bean (White bean), Large seeded bean (Large red bean), Pinto bean (mottled brown bean) (Fig. 3).

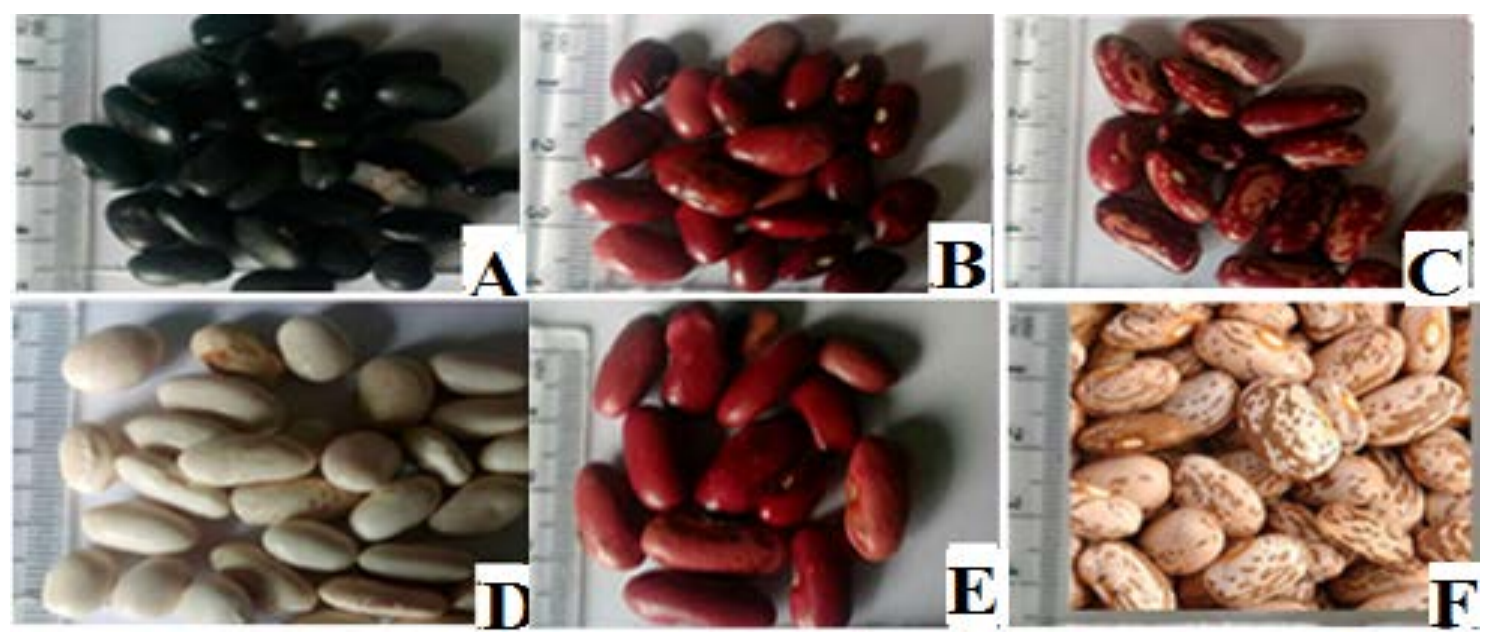

Fig. 3 - Cultivars of common bean collected from Menoua Division, Cameroon. A Black bean. B Kidney bean (small sized red bean). C Pea bean (mottled red bean) D Navy bean. E Large seeded bean (Large red bean). F Pinto bean (mottled brown bean).

\section{Surface sterilization of common bean samples}

All common bean samples (both harvest and stored) collected from the subdivisions were brought to the University of Buea Plant Science Laboratory, Cameroon for fungal isolation. Specific sterilization protocol (Schulz et al. 1993) was used for the maximum recovery of fungi. 
Five replicates of 50 common bean grains of each cultivar type per treatment were immersed in $70 \%$ ethanol for 1 minute. Surface sterilization of the grains was done using $10 \%$ sodium hypochlorite solution for 1 minute. Finally, the grains were rinsed with distilled water for 3 minutes. The common bean grains were then blot-dried with sterile filter paper.

\section{Direct plating of common bean cultivars for detection and isolation of fungi}

The sterilized common bean grains (both during harvest and storage) obtained from the different cultivars were then plated on Potato Dextrose Agar (PDA) media. The plating of the common bean grains was done at a rate of 10 bean grains per plate (Fig. 4). The grains were placed evenly in the plates. The plates were covered by their lids and fastened using parafilm. The sealed plates were then maintained under incubation at $28 \pm 2{ }^{\circ} \mathrm{C}$ for 7 days to promote fungal growth.

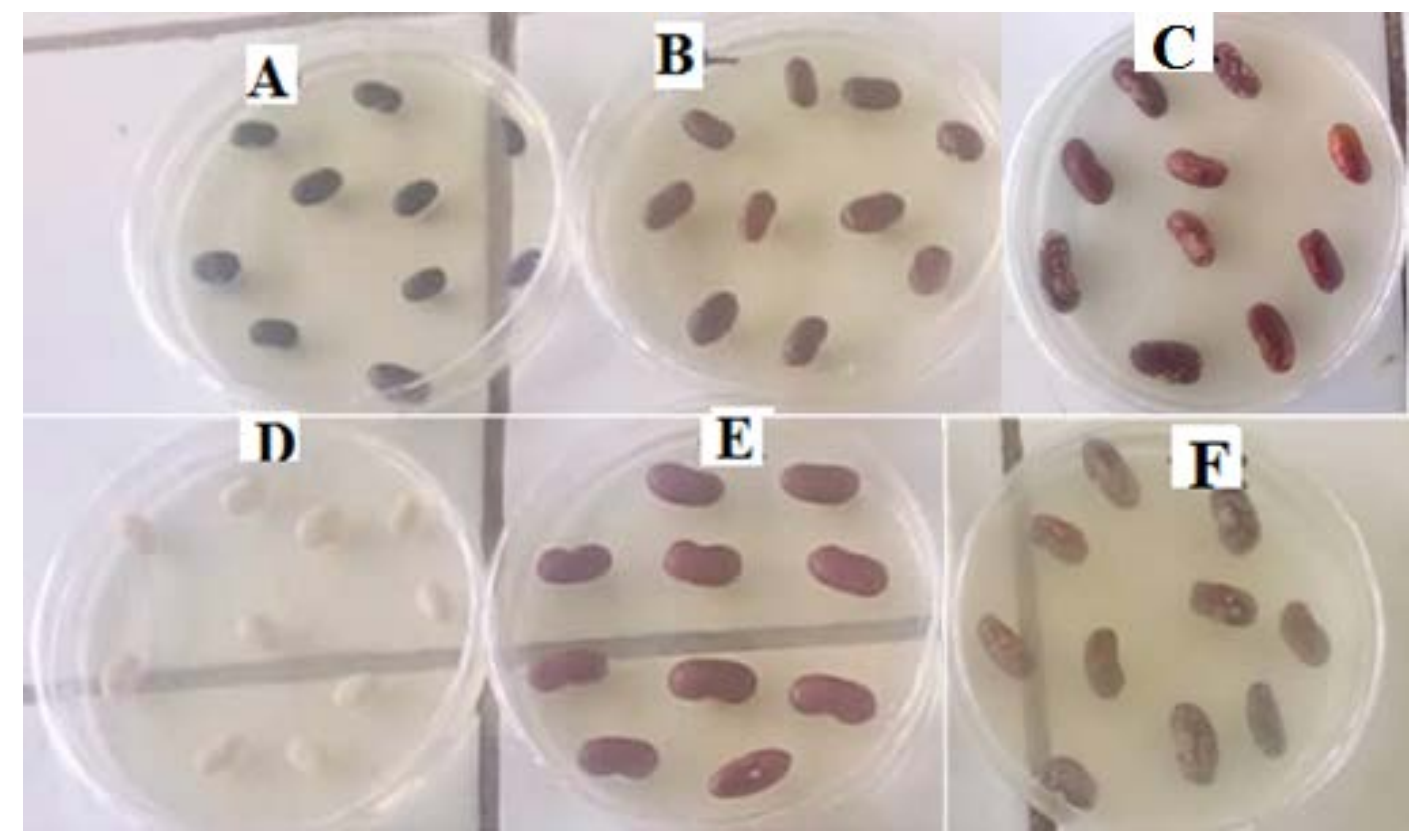

Fig. 4 - Common bean cultivars directly plated on PDA for isolation of fungi. A Black bean. B Kidney bean (small sized red bean). C Pea bean (mottled red bean). D- Navy bean. E Large seeded bean (Large red bean). F- Pinto bean (mottled brown bean).

\section{Determination of the incidence of common bean infection by fungi}

The incidence of common bean infection by fungi was established by counting the number of plated common bean grains showing fungal growth on their surface and expressing as a percentage of the total grains plated. Incidence showed the extent of damage of the grain by fungi. A high fungal incidence on grain correlates with extensive damage of the grain (Tibagonzeka et al. 2018).

$$
\text { Incidence }=\frac{\text { Noof seeds with fungus }}{\text { Number of seeds plated }} \times 100 \%
$$

\section{Morphological identification of fungi from common bean cultivars}

Identification of fungal isolates was done using macro-micro morphological characteristics. Cultural characteristics of the fungi in terms of growth, colony character, texture and sporulation on medium was noted. Colony coloration was determined using the Methuen handbook in accordance to Kornerup \& Wanscher (1978). Identification of fungi using macro-micro morphological features was done in accordance to Klich (2002) and findings compared using established keys as described by (Barnett \& Hunter 1998). Fungal cultures that could not sporulate were classified as 'Mycelia sterilia' and sorted to Morphospecies based on cultural characteristics (Lacap et al. 2003). 


\section{Frequency of fungal isolation}

The frequency of fungi isolated was established by counting the number of times each fungal colony occurred on the plated bean cultivars. This was expressed as a percentage.

$$
\% \text { Frequency }=\frac{\text { occurence of fungal isolate on cultivar }}{\text { total number of isolates on cultivar }} \times 100 \%
$$

\section{Statistical analysis}

Data on the incidence of infection by fungi on the different common bean cultivars obtained were entered in a Microsoft Excel spread sheet and normality was determined. One-way analysis of variance (ANOVA) and means comparison using Tukey's test $(\alpha=0.05)$ was performed to check whether the incidence of fungal infection on the different cultivars tested differed significantly. Results of incidence of fungi on cultivars were expressed as Mean \pm SE values. Results were finally presented on tables.

A t- test was used to compare the mean incidence level of fungal infection between the two groups of cultivars (during storage and during harvest).

\section{Results}

\section{Fungal growth on plated common bean}

After the period of incubation of plated common bean grains, fungal growth was observed on the plates of the different cultivars; during harvest (Fig. 5) and during storage (Fig. 6). The growth of fungi was recognized by the presence of mycelia emerging from the bean and on the growth medium. Plated grains also showed changes in colour. Molding and germination were also observed on some of the plated grains. Presence of fungal spores was noticed on some surfaces of the plated common bean grains. There was also a musty odour of the plated bean grains which signified mold invasion.

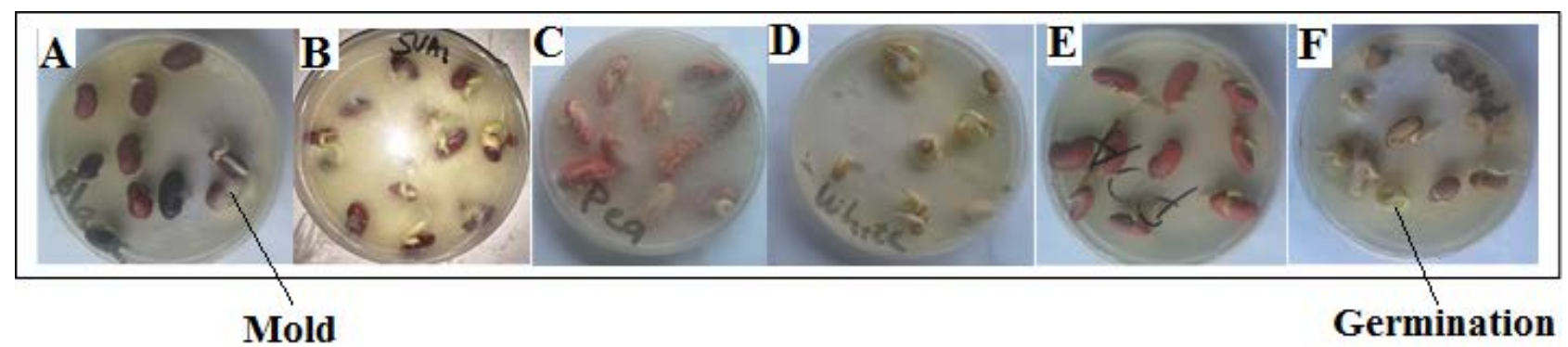

Fig. 5 - Fungal growth on plated bean cultivars during harvest. A Black turtle bean (Black bean). B Kidney bean (small sized red bean). C Pea bean (mottled red bean). D Navy bean (White bean). E Large seeded bean (Large red bean). F Pinto bean (mottled brown bean).

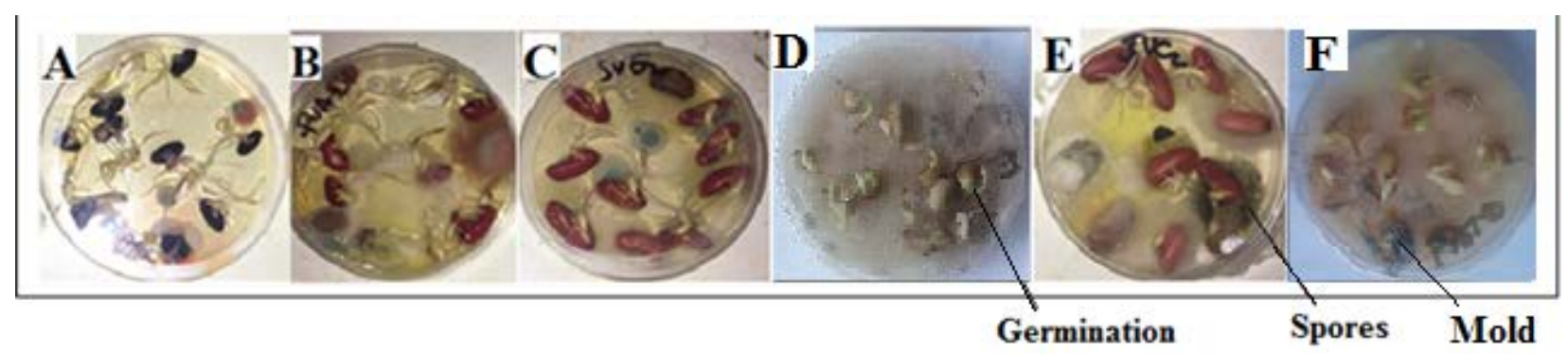

Fig. 6 - Fungal growth on plated stored bean cultivars. A Black turtle bean (Black bean). B Kidney bean (small sized red bean). C Pea bean (mottled red bean). D Navy bean (White bean). E Large seeded bean (Large red bean). F Pinto bean (mottled brown bean). 


\section{Incidence of common bean infection by fungi during harvest}

During harvest, a total of 31 out of the 300 plated common bean grains were shown to be infected by fungi. This gave an incidence level of infection of $10.33 \%$.

There was no significant difference $(\mathrm{P}>0.05)$ in the mean incidence of infection by fungi on the different cultivars during harvest (Table 1).

Table 1 Mean incidence of common bean infection by fungi during harvest

\begin{tabular}{lll}
\hline $\begin{array}{l}\text { Common bean cultivars during } \\
\text { harvest }\end{array}$ & $\mathbf{N}$ & $\begin{array}{l}\text { Mean incidence of infection of common } \\
\text { bean cultivars }\end{array}$ \\
\hline kidney bean & 5 & $8.00 \pm 3.74$ \\
Black bean & 5 & $16.00 \pm 2.45$ \\
Large seeded bean & 5 & $14.00 \pm 2.45$ \\
Pinto bean & 5 & $8.00 \pm 3.74$ \\
Pea bean & 5 & $10.00 \pm 3.16$ \\
Navy bean & 5 & $6.00 \pm 2.45$ \\
$\mathrm{P}=0.194(\mathrm{P}>0.05)$ & \multicolumn{2}{c}{} \\
$\mathrm{N}=$ number of replicates. Values are expressed as means \pm SE for five replicates
\end{tabular}

\section{Incidence of common bean infection by fungi during storage}

All of the stored common bean cultivars were shown to be infected by fungi. Eighty stored common bean grains out of a total of 300 plated yielded fungal growth. This gave an incidence level of infection of $26.67 \%$.

A significant difference $(\mathrm{P}<0.05)$ in the in the mean incidence of common bean infection by fungi was observed during storage (Table 2).

Table 2 Mean Incidence of common bean infection by fungi during storage

\begin{tabular}{lll}
\hline Common bean Cultivar type & $\mathbf{N}$ & $\begin{array}{l}\text { Mean incidence of infection of common } \\
\text { bean cultivars }\end{array}$ \\
\hline Red bean & 5 & $34.00 \pm 11.40^{\mathrm{b}}$ \\
Black bean & 5 & $26.00 \pm 15.17^{\mathrm{b}}$ \\
Large seeded red & 5 & $44.00 \pm 8.94^{\mathrm{a}}$ \\
Pinto bean & 5 & $22.00 \pm 4.47^{\mathrm{c}}$ \\
Pea bean & 5 & $22.00 \pm 13.04^{\mathrm{c}}$ \\
Navy bean & 5 & $12.00 \pm 8.37^{\mathrm{c}}$ \\
$\mathrm{P}=0.002(\mathrm{P}<0.05)$ & & \\
\hline
\end{tabular}

$\mathrm{N}=$ number of replicates. Values are expressed as means \pm SE for five replicates

a,b,c Means accompanied by different superscripts differ significantly at $\mathrm{P}<0.05$

From the result indicated, the mean incidence of infection of the bean cultivars during storage due to fungi was shown to differ significantly $(\mathrm{P}<0.05)$. The large red seeded cultivar had the highest $(\mathrm{P}<0.05)$ mean incidence level of infection $(44.00 \pm 8.94)$. Lower fungal communities were observed in Pinto bean cultivar, Pea bean cultivar and Navy bean cultivar with mean incidence infection levels of $22.00 \pm 4.47,22.00 \pm 13.04$, and $12.00 \pm 8.37$ respectively. No significant difference in the incidence of infection was observed between these cultivar types.

A comparison of the mean incidence level of infection by fungi in the two groups of cultivars (bean cultivars during harvest and bean cultivars during storage) in the Menoua Division using an independent t- test analysis revealed a significant difference between their mean incidence of infection (Table 3).

The result of the analysis showed that the calculated t-value of 5.03 was higher than the critical t-value of 1.96 at a 0.05 level of significance with 111 degrees of freedom (df). Therefore, the mean incidence of common bean infection by fungi was higher during storage than during harvest. 


\section{Morphological identification of fungi isolated from common bean cultivars}

Based on micro-macro morphological characteristics (Table 4) a total of four distinct fungal species were isolated from the common bean cultivars (Fig. 7). These species were; Aspergillus sp., Penicillium sp., Fusarium sp., and 'Mycelia sterilia'. The Mycelia sterilia was termed Morphospecie.

Table 3 Analysis of the incidence of fungal infection between groups of cultivars

\begin{tabular}{lllll}
\hline Cultivars & N & Mean incidence & SD & t-value \\
\hline Bean cultivars during storage & 80 & 26.67 & 2.60 & $5.03^{* *}$ \\
Bean cultivars during harvest & 31 & 10.33 & 1.31 & \\
Total & 111 & 18.5 & 1.96 & \\
\hline$<0.05, \mathrm{df}=111$, critical $\mathrm{t}=1.96, \mathrm{~N}$ & $=$ number & of common bean grains infected &
\end{tabular}
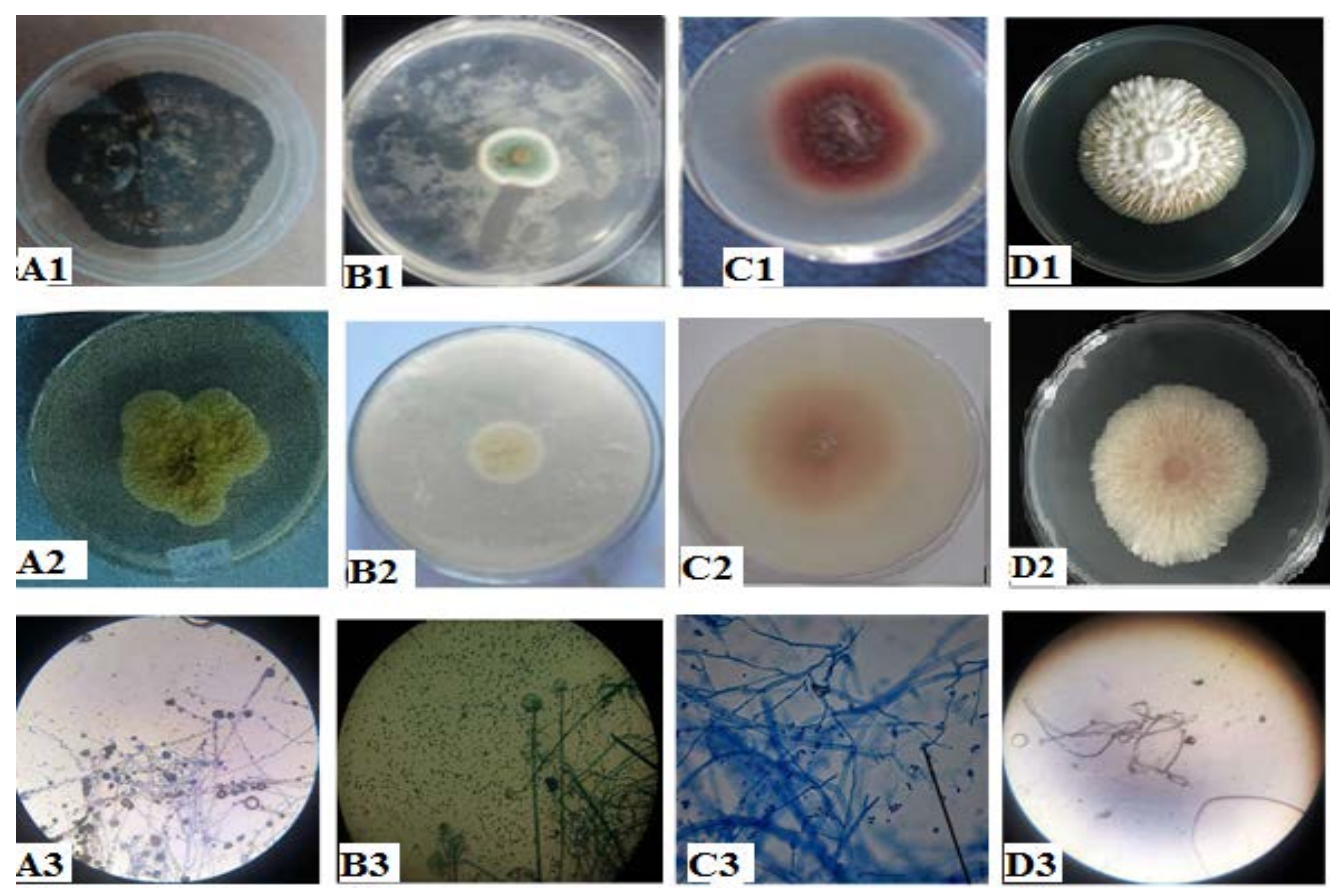

Fig. 7 - Colonial characteristics of fungal isolates (surface view A1 - D1). A1 Aspergillus sp. B1 Penicillium sp. C1 Fusarium sp. D1 Morphospecie. Colonial characteristics of fungal isolates (reverse view A2 - D2). A2 Aspergillus sp. B2 Penicillium sp. C2 Fusarium sp. D2 Morphospecie. Microscopic images of fungal isolates A3 - D3 (x40). A3 Aspergillus sp. B3 Penicillium sp. C3 Fusarium sp. D3 Morphospecie.

Table 4 Morphological characterization and identification of isolated fungi from common bean cultivars.

\begin{tabular}{ll}
\hline Fungi species & Macro and Micro characteristics \\
\hline $\begin{array}{l}\text { Aspergillus sp. } \\
\text { (A1, A2 and A3) }\end{array}$ & $\begin{array}{l}\text { Colonies fast growing, yellow to dark on the surface and creamy yellow on the } \\
\text { reverse side. Microscopically, the conidiophores bore phialides on their entire } \\
\text { surface. Globose vesicles held on long conidiophores and smooth globose } \\
\text { conidia }\end{array}$ \\
$\begin{array}{l}\text { Colonies appeared green on the surface and creamy on the reverse. Conidia were } \\
\text { (B1, B2 and B3) }\end{array}$ & $\begin{array}{l}\text { borne in unbranched chains, arising from bundles of cylindrical to bottle shaped, } \\
\text { phialides closely arranged in a brush-like head }\end{array}$ \\
Fusarium sp. & $\begin{array}{l}\text { Colonies fluffy, pink red on the surface and light pink on the reverse. Curved } \\
\text { microconidia produced on simple, short phialides. Conidia had more than one } \\
\text { (C1, C2 and C3) }\end{array}$ \\
\hline
\end{tabular}


Table 4 Continued.

\begin{tabular}{ll}
\hline Fungi species & Macro and Micro characteristics \\
\hline $\begin{array}{l}\text { Morphospecie } \\
\text { ('mycelia sterilia') }\end{array}$ & Colonies with mycelia white both on the surface and reverse. Colony with \\
(D1, D2 and D3) & \\
\hline
\end{tabular}

The isolation frequencies and percentage of occurrence of the fungal species from the various common bean cultivars is shown (Table 5). Fusarium sp. had no occurrence on the pinto bean, pea bean and black bean cultivar. The Morphospecie (Mycelia sterilia) was most frequently isolated from all the common bean cultivars.

Table 5 Frequency and Percentage of Occurrence of the different fungal species, as isolated from Common Bean Cultivars on PDA.

\begin{tabular}{|c|c|c|c|c|c|c|c|c|c|c|c|c|}
\hline \multirow[b]{2}{*}{ Fungi species } & \multicolumn{12}{|c|}{ Common bean cultivar type } \\
\hline & Kidney & $\%$ & $\begin{array}{l}\text { Black } \\
\text { bean }\end{array}$ & $\%$ & $\begin{array}{l}\text { Large } \\
\text { seeded }\end{array}$ & $\%$ & $\begin{array}{l}\text { Pinto } \\
\text { bean }\end{array}$ & $\%$ & $\begin{array}{l}\text { Pea } \\
\text { bean }\end{array}$ & $\%$ & $\begin{array}{l}\text { Navy } \\
\text { bean }\end{array}$ & $\%$ \\
\hline Morphospecie & 17 & 80.95 & 15 & 71.43 & 15 & 51.72 & 9 & 60.0 & 7 & 46.67 & 4 & 44.44 \\
\hline $\begin{array}{l}\text { Aspergillus } \\
\text { sp. }\end{array}$ & 2 & 9.52 & 4 & 19.05 & 10 & 34.48 & 1 & 6.67 & 7 & 46.67 & 1 & 11.11 \\
\hline $\begin{array}{l}\text { Penicillium } \\
\text { sp. }\end{array}$ & 1 & 4.76 & 2 & 9.52 & 3 & 10.35 & 5 & 33.33 & 1 & 6.67 & 1 & 11.11 \\
\hline Fusarium sp. & 1 & 4.76 & 0 & 0 & 1 & 5.27 & 0 & 0 & 0 & 0 & 3 & 33.33 \\
\hline $\begin{array}{l}\text { Total number } \\
\text { of isolates }\end{array}$ & 21 & & 21 & & 29 & & 15 & & 15 & & 9 & \\
\hline
\end{tabular}

\section{Discussion}

From the study carried out, common bean cultivars during harvest were found to harbor fungi; with a mean incidence level of infection being 10.33\%. Fungi during harvest are those that originate from the field due to high moisture content (Sweets 2018). Studies done by Scariot et al. (2017) in Brazil on the moisture contents of common bean seeds indicated a high moisture level on the seeds at harvest. High moisture levels in grains predispose them to growth of fungi (Magan et al. 2004). In the Menoua Division of Cameroon, common bean is harvested during the rainy season at high moisture conditions which thereby predisposes the grains to fungal infection.

Results during harvest showed no significant difference $(\mathrm{P}>0.05)$ in the fungal incidence of infection between the different common bean cultivars. This investigation presented an almost equal distribution of infection level among the cultivars during harvest. The mean incidence of bean infection by fungi during harvest was low $(\mathrm{P}<0.05)$ compared to the mean incidence of infection at storage. Studies have shown that fresh grains still have defense mechanism (ICMSF 1998). This therefore serves as a barrier for infections by microorganisms. One typical defense mechanism is the release of the defense enzyme polyphenol oxidase on the seed coats (Mayer 2006). Four potential mechanisms by which polyphenol oxidase may inhibit microorganisms include; toxicity and antimicrobial activity of quinone products, decreased bioavailability of proteins and nutrients, creation of lignin-like mechanical barriers, and participation in the generation of reactive oxygen radicals (Constabel \& Barbehenn 2008). The action of Polyphenol oxidase alongside the accumulation of polyphenols has also been shown typically to be associated on the seed coat of Pinto bean which also characterizes post-harvest color changes (Marles et al. 2008).

Stored common bean cultivars were shown to be infected with fungi. The incidence of infection of bean cultivars during storage by fungi was $26.67 \%$. This was in agreement with AlAbdalall (2008) who recorded a similar result of $26.1 \%$ of fungal incidence of stored beans in Dammam province, kingdom of Saudi Arabia. Mean incidence of fungi on stored common bean cultivars was relatively high $(\mathrm{P}<0.05)$ as compared to cultivars during harvest. Studies carried out 
by Kumari et al. (2019) on stored food grains in some regions in India demonstrated that the contamination of food grains by fungi increases with their duration of storage. Based on field analysis it was seen that farmers in the Menoua division of Cameroon stored their common bean cultivars after harvest in gunny bags and these bags are usually in direct contact with the floor surface which favors the development of moisture within the bean grains in the bag. Moisture is a major factor that contributes to the development of fungi in stored seeds (Magan et al. 2003).

Fabiana \& Roberto (2008) showed that there is usually a decrease in the population of field fungi on grains at post harvest and a rise in the population of storage fungi. This may be associated to abiotic factors, some of which includes temperature; moisture and oxygen content (De Lucia \& Assennato 2006). Stored fungi exhibit rapid growth at temperatures between $25{ }^{\circ} \mathrm{C}$ to $32{ }^{\circ} \mathrm{C}$ (Beckett 2011). This temperature coincides with the climatic temperature of Menoua Division which therefore makes it favorable for the growth of these storage fungi. Farmers in Menoua Division mostly store beans in gunny bags after harvest. Studies by Golob (2009) showed that use of poor storage structures by farmers; like polypropylene bags, granaries, above fire racks in the kitchen, plastic bags and other containers favors growth of mold as some of these structures do not protect common bean from picking up environmental moisture hence predisposing the stored bean to mold infection. The mode of transportation of food commodities from farms after harvest could also be a contributing factor to further contamination by fungi species since most of the food commodities are not usually transported properly due to inadequate finances. Storage fungi on grains usually occur at low levels during pre-harvest but during post-harvest, there occur at relatively higher levels and show a wide distribution (IRRI 2006). Fungi contaminants can spread even from minute amount of spores that settled on the grain from the field as it is taken to be stored. Fungal spores can also be transferred to grains either through handling, storage equipment or from spores that were already present in the storage structures. Under conditions of high temperature and moisture, the minute amount of inoculant can spread rapidly (Kange et al. 2015).

Lower incidence levels of infection during storage were observed in Pinto bean cultivar, Pea bean cultivar and White cultivar with mean fungi population values $22.00 \pm 4.47,22.00 \pm 13.04$, and $12.00 \pm 8.37$ respectively. These cultivars were designated the least susceptible to fungal infection. The lower colonization of these cultivars by fungi can also be linked to the integrity of their seed coat which acts as a physical barrier to fungal invasion. Polyphenol oxidase an enzyme responsible for the defense mechanism in plant has also been shown typically to be associated on the seed coat of Pinto beans (Marles et al. 2008). Polyphenol oxidase activity localized in the seed coat has also been shown to play a major role in seed coat hardening which resist attack of seeds by pathogens. Similar research carried out in Laikipia, Kenya showed that the white bean cultivar was highly resistant to anthracnose; a fungi disease of plant than other common bean cultivars (Wagara \& Kimani 2007). This therefore shows that the incidence of infection of bean cultivars by fungi also depend on the type of cultivar.

Highest fungal incidence level was observed in large seeded cultivar having mean incidence level of infection of $44.00 \pm 8.94$. This cultivar was designated the most susceptible to fungal infection. Reports indicate that the large size of bean seeds hinders the process of drying and storage as the seeds offer a low resistance to the flow of air. More time is therefore taken to move moisture from the inside to the outside of the seed. This creates a favorable environment or hotspot for the growth of fungi (Biddle et al. 1988). Similar research done in Uganda shows that resistance to Fusarium solani on common bean seeds has been associated with seed size. Small seeded common bean have been found to be more resistant to Fusarium solani than large seeded bean (Clare et al. 2010). It has been reported that large-seeded red bean cultivar is the most cultivated and consumed common bean cultivar in Kenya (Korir et al. 2005). Similar studies done in Kenya on common bean have proven that the large red seeded common bean cultivar is moderately resistant to the fungal disease anthracnose (Wagara \& Kimani 2007). The presence of resistant genes has also been shown to be a contributing factor to barriers of common bean cultivars to infection (Singh 2001). Fusarium solani that causes Fusarium rot has been reported to have the 
greatest impact on large-seeded bean cultivars as a result of lack of genetic resistance in these seed types (Schneider et al. 2001).

\section{Conclusion}

This is the first intensive study assessing the incidence of common bean infection by fungi in the Menoua Division. From this study, it was observed that long term storage of common bean harbors a great proportion of fungi. The species of fungi recovered from the bean cultivars signified poor management methods carried out both in field and after harvest in this region of Cameroon. The susceptibility of cultivars to fungi also depends on the type of cultivar. The large seeded bean cultivar was the most susceptible to fungal infection upon storage. Due to the nutritional benefits of common bean, it is therefore necessary to improve on its storage conditions so as to reduce postharvest fungal infections.

\section{Acknowledgements}

The authors are thankful for the support provided by farmers of Menoua Division for the provision of common bean cultivars and also to the staff of Plant Pathology Laboratory of the University of Buea for all laboratory assistance.

\section{Ethics declaration}

\section{Ethical statement}

This article does not contain any studies with human participants or animals performed by any of the authors.

\section{Conflict of interest}

The authors declare that they have no conflict of interest.

\section{Consent for publication}

As Corresponding Author, I confirm that the manuscript has been read and approved for submission by all the named authors.

\section{References}

Al-Abdalall AH. 2008 - Pathological Studies of Fungi Associated with Pulse Seeds during Storage in Dammam Province, Kingdom of Saudi Arabia. Middle Eastern and Russian Journal of Plant Science and Biotechnology, 2(2), 71-77.

Alemu H. 2017 - Review Paper On Breeding Common Bean (Phaseolus Vulgaris L.) Genotypes For Acidic Soil Tolerance.

Barnett H, Hunter B. 1998 - Illustrated genera of imperfect fungi 4th ed. The American Phytopathological Society. Minnesota. USA.

Beckett S. 2011 - Insect and mite control by manipulating temperature and moisture before and during chemical-free storage. Journal of stored products research, 47(4), 284-292.

Biddle A, Gent G, Knott C. 1988 - The PGRO pea growing handbook: Processors \& Growers Research Organisation

Buruchara R, Chirwa R, Sperling L, Mukankusi C et al. 2011 - Development and delivery of bean varieties in Africa: the Pan-Africa Bean Research Alliance (PABRA) model. African Crop Science Journal, 19(4), 227-245.

Clare MM, Melis R, Dereta J, Laing M, Buruchara RA. 2010 - Identification of sources of resistance to Fusarium root rot among selected common bean lines in Uganda. Journal of Animal \& Plant Sciences, 7(3), 876-891

Constabel CP, Barbehenn R. 2008 - "Defensive roles of polyphenol oxidase in plants," in Induced Plant Resistance to Herbivory ed. Schaller A., editor. (Dordrecht: Springer Science and Business Media B.V.) 253-269. Doi: 10.1007/978-1-4020-8182-8_12

De Lucia M, Assennato D. 2006 - Agricultural engineering in development: post-harvest operations and management of food grains. FAO Agricultural Services Bulletin (FAO). 
Dongmo AL, Ijang TP, Tuete A, Okolle Jet al. 2014 - A situational analysis of agricultural production and marketing, and natural resources management systems in the humid tropical zones of Cameroon.

Fabiana GF, Roberto US. 2008 - Seed Health of common beans. Journal of agricultural Science (Piracicaba, Brazil), 65 (6), 613-619. Doi: 10.1590/S0103-90162008000600007

Ghangaokar NM, Kshirsagar AD. 2013 - Study of seed borne fungi of different legumes. Trends in Life Sciences, 2(1), 32-35

Golob P. 2009 - On-farm post-harvest management of food grains: a manual for extension workers with special reference to Africa. Agricultural and food engineering training and resource materials, (2).

ICMSF. 1998 - Micro-Organisms in Foods: Microbial Ecology of Food Commodities: Springer US.

INS. 2017 - Annual statistics of the West region of Cameroon. Accessed 2 Mar 2020. https://www.citypopulation.de/en/cameroon/cities/

IRRI. 2006 - International Rice Research Institute. Accessed 20 Nov 2014

www.knowledgebank.irri.org/ppfm/storage/6.B.-fungi.ht

Kamtchoum SM, Nuemsi PK, Tonfack LB, Edinguele DG et al. 2018 - Production of Bean (Phaseolus vulgaris L.) under organo-mineral fertilization in humid forest agro-ecological zone with bimodal rainfall pattern in Cameroon. Annual Research \& Review in Biology, 111. Doi: $10.9734 / A R R B / 2018 / 44607$

Kange AM, Cheruiyot EK, Ogendo JO, Arama PF. 2015 - Effect of sorghum (Sorghum bicolor L. Moench) grain conditions on occurrence of mycotoxin-producing fungi. Agriculture \& Food Security, 4(1), 15.

Klich MA. 2002 - Identification of common Aspergillus species.

Kornerup A, Wanscher JH. 1978 - Methuen Handbook of Colour. Eyre Methuen Ltd.

Korir M, Odhiambo M, Iruria D, Kipsat M, Serem A. 2005 - Bean Varietal preference in East African markets and its implications to breeding. Paper presented at the African Crop Science Conference proceedings.

Kumari R, Jayachandran LE, Ghosh AK. 2019 - Investigation of diversity and dominance of fungal biota in stored wheat grains from governmental warehouses in West Bengal, India. Journal of the Science of Food and Agriculture, 99(7), 3490-3500. Doi: doi.org/10.1002/jsfa.9568

Lacap D, Hyde KD, Liew E. 2003 - An evaluation of the fungal 'morphotype' concept based on ribosomal DNA sequences. Fungal Diversity.

Magan N, Hope R, Cairns V, Aldred D. 2003 - Post-harvest fungal ecology: impact of fungal growth and mycotoxin accumulation in stored grain Epidemiology of Mycotoxin Producing Fungi 723-730: Springer.

Magan N, Sanchis V, Aldred D. 2004 - Role of spoilage fungi in seed deterioration. Fungal biotechnology in agricultural, food and environmental applications, 311-323.

Marles MA, Vandenberg A, Bett KE. 2008 - Polyphenol oxidase activity and differential accumulation of polyphenolics in seed coats of pinto bean (Phaseolus vulgaris L.) characterize postharvest color changes. Journal of Agriculture and Food Chemistry 56: 70497056. Doi: 10.1021/jf8004367 [PubMed].

Mayer AM. 2006 - Polyphenol oxidases in plants and fungi: A review. Phytochemistry, 67(21), 2318-2331.

Pitt JI, Hocking AD. 2009 - Fungi and food spoilage (Vol. 519). New York: Springer.

Scariot MA, Tiburski G, Reichert Júnior FW, Radünz LL, Meneguzzo MR. 2017 - Moisture content at harvest and drying temperature on bean seed quality. Pesquisa Agropecuária Tropical, 47(1), 93-101.

Schneider KA, Grafton KF, Kelly JD. 2001 - QTL analysis of resistance to Fusarium root rot in bean. Crop Science, 41(2), 535-542. Doi: 10.2135/cropsci2001.412535x 
Schulz B, Wanke U, Draeger S, Aust HJ. 1993 - Endophytes from herbaceous plants and shrubs: effectiveness of surface sterilization methods. Mycological research, 97(12), 1447-1450. Doi: 10.1016/S0953-7562(09)80215-3

Seebold KW. 2014 - Bean Diseases. University of Kentucky-Colle of Agriculture, Food and Environment-Plant Pathology Extension, 16, 1-6.

Seino R, Dongmo T, Ghogomu R, Kekeunou S et al. 2013 - An inventory of short horn grasshoppers in the Menoua Division, West Region of Cameroon. North American Journal of agriculture, 4(3), 291-299.

Singh SP. 2001 - Broadening the genetic base of common bean cultivars. Crop Science, 41(6), 1659-1675

Sweets L. 2018 - Stored grain fungi. Agricultural Electronic Bulletin Board University of Missouri Extension-CAFNR.

Tankou CM, De Snoo GR, Persoon G, de Iongh HH. 2017 - Evaluation of smallholder farming systems in the Western Highlands of Cameroon. Evaluation, 7(1).

Tibagonzeka JE, Akumu G, Kiyimba F, Atukwase et al. 2018 - Post-harvest handling practices and losses for legumes and starchy staples in Uganda. Agricultural Sciences, 9(1), 141-156.

Wagara I, Kimani P. 2007 - Resistance of nutrient-rich bean varieties to major biotic constraints in Kenya. Paper presented at the African Crop Science Conference Proceedings). 